\title{
Devlet Adamı C. Abdrahmanov ve Günlüğünün Tarihi Kaynak Olarak Değerlendirilmesi*
}

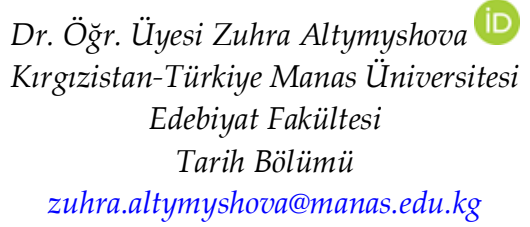

\author{
Doç. Dr. Leila Hasanaeva \\ Al-Farabi Kazak Milli Üniversitesi \\ Tarih, Arkeoloji ve Etnoloji Fakültesi \\ Kazakistan Tarihi Bölümü \\ leila_hassanaeva@mail.ru
}

Öz

Bilindiği gibi, Komünist ideolojinin hâkim olduğu Sovyet toplumunda serbest fikir ifade edebilmek yasaktı. Devlet tarafından sıkı bir biçimde uygulanan sansürden dolayı, tarih alanındaki bilimsel eserler de taraflı yansitıliyordu. Bu sebeple, günümüzde Sovyet dönemi tarihinin kapsamlı bir şekilde araştırılmasında her türlü yazılı kaynağı incelemek önemlidir. Kırgızistan'da Sovyet rejimi kurulduktan sonra birçok üst düzey devlet görevlerinde bulunan Cusup (yada Yusup) Abdrahmanov aynı zamanda pek çok önemli eseri kaleme almıştır. C. Abdrahmanov 1916 İsyanı, 1917 Şubat ve Ekim İhtilalleri dönemi ve 1920 ve 1930'larda Sovyet Kırgizistan'ın siyasî, sosyoekonomik ve kültür tarihi ile ilgili konuları ele alan eserleri ile bilinmektedir. Bunlarla birlikte Cusup Abdrahmanov'un Rusça yazılmış olan ve gizli tuttuğu günlüğü mevcuttur. C. Abdrahmanov'un günlüğü o dönemde yeni kurulan Sovyet yönetiminin uygulamaları hakkında geniş bilgiler sunmaktadır. 19201930'larda C. Abdrahmanov devlet adamı olmasından dolayı kolhozlaştırma, sanayileşme, Kırgızların yerleşik hayata geçirilmesi, Sovyet Kültür Devrimi gibi sosyalist düzenlemelerin uygulama süreçlerine direk katılmıştır. Ve günlügüunde onlar hakkında kendi düşüncelerini serbestçe kâğıda dökmüş ve çoğu zaman Sovyet yönetiminin sosyalist faaliyetleri uygulama sürecinde halka yönelik zorlama yöntemlerini eleştirmiştir. Ayrıca, C. Abdrahmanov günlüğünde 1930'lu yılların başlarında Kazakistan'da ortaya çıkan olağanüstü açlık ve sebepleri, Kırgızistan'a sığınan Kazaklar hakkında da bilgileri ve bu konudaki düşüncelerini aktarmaktadır. Kırgız devlet adamı ve aydın C. Abdrahmanov Sovyet devletinin uyguladığı şiddetli 1937-1938 Repressiya döneminde hapsedilerek öldürülmüştür. Makalede C. Abdrahmanov'un hayatı ve faaliyetleri üzerinde durulacaktır, ayrıca C. Abdrahmanov tarafından kaleme alınan günlüğü de tahlil edilecektir. Konu, Sovyet arşiv belgeleri ve bilimsel eserlerin ışı̆̆ında ele alınacaktır.

Anahtar Kelimeler: C. Abdrahmanov'un günlüğü, Sovyet yönetimi, Kırgızistan, kolhozlaştırma, sanayileşme.

\footnotetext{
${ }^{*}$ Makale Yeditepe Üniversitesi tarafından 1-2 Kasım 2018 tarihinde İstanbul'da düzenlenen II. Uluslararası Türk Kültürü ve Tarihi Sempozyumu'nda sunulan bildirinin düzenlenmiş ve genişletilmiş halidir. 


\title{
Statesman J. Abdrakhmanov and the Evaluation of His Diary as a Historical Source
}

\begin{abstract}
As it is known, it was forbidden to express free opinion in Soviet society dominated by the Communist ideology. Due to the strict censorship implemented by the state, scientific works in the field of history were also reflected one-sidedly. For this reason, today it is important to examine different written sources in the comprehensive research of the history of the Soviet period. Jusup (or Yusup) Abdrakhmanov, who held a number of high-level government positions, after the establishment of the Soviet regime in Kyrgyzstan, also wrote important works. J. Abdrakhmanov is known for his works about the 1916 Revolt, the period of 1917 the February and the October Revolutions, the political, socio-economic and cultural history of the Soviet Kyrgyzstan in the 1920s and 1930s. Together with them, there is a diary left by Jusup Abdrakhmanov, which is written in Russian. J. Abdrakhmanov's diary provides extensive information on the organization of the newly established Soviet administration at that time. In 1920-1930s, J. Abdrakhmanov had directly participated in the implementation processes of socialist organization such as collectivization, industrialization, transition of the Kyrgyz to the settled life and Soviet Cultural Revolution due to his role as a statesman. He wrote his thoughts freely about them in his diary and often criticized forced methods of the Soviet government towards the people in implementing socialist organization. In addition, in his diary J. Abdrakhmanov reports the extraordinary famine and its causes in Kazakhstan in the beginning of 1930s, and he gives information and reflects his ideas about the Kazakhs, who took refuge in Kyrgyzstan. Kyrgyz statesman and intellectual J. Abdrakhmanov was imprisoned and died during the violent 1937-1938 Repression period applied by the Soviet state. The article will focus on J. Abdrakhmanov's life, his activities, and the diary written by J. Abdrakhmanov will be analyzed. The subject will be evaluated in the light of the Soviet archival documents and scientific works.
\end{abstract}

Keywords: Soviet government, Kyrgyzstan, J. Abdrakhmanov's diary, collectivization, industrialization. 


\section{GíRIŞ}

Tarih biliminde geçmiş olayların objektif olarak araştırılmasında arşiv belgeleri ile bilimsel eserlerin yanı sıra hatıratlar, süreli yayınlar, günlük, kronikler, biyografiler ve seyahatnameler yazılı kaynakları oluşturmaktadır. Bazı tarih meselelerinin gün ışığına çıartılmasında bu tür yazılı kaynaklar yardımcı kaynak niteliğindedir. Özellikle Sovyet dönemi tarihinin kapsamlı bir şekilde araştırılmasında ilgili yazılı kaynaklara başvurmak önemlidir. Çünkü Sovyet dönemi boyunca tarih bilimindeki araştırmalar sıkı uygulanan sansür süzgecinden geçirilerek Komünist Partinin başta bulunduğu yönetimin ideolojisini ve siyasetini yansıtır şekilde tek taraflı ele alınıyordu.

Sovyet rejimi kurulduktan sonra 1920-1930'larda Kırgizistan'da Halk Komiserler Kurulu başkanlığı olmak üzere birçok üst düzey devlet görevlerinde bulunan Cusup Abdrahmanov aynı zamanda bir kaç önemli eserin yazarıdır. C. Abdrahmanov eserlerinde 1916 İsyanı, 1917 Şubat ve Ekim İhtilalleri dönemi ve 1920-1930'lu yıllarda Sovyet Kırgizistan'ın tarihi ile ilgili konularda bilgi vermektedir. Cusup Abdrahmanov eserleriyle birlikte Rus dilinde kaleme aldığı gizli günlügünü miras bırakmıştır. Adı geçen günlük Sovyet dönemi Kırgızistan'ın tarihi hakkında ayrıntılı ve ilginç bilgiler içermesi sebebiyle önemli bir bilimsel kaynak olma özelliği taşımaktadır. C. Abdrahmanov Sovyet yönetiminin planladığı sosyoekonomik meselelere gerçekçi yaklaşması sebebiyle 1920'li yılların sonu ve 1930'lu yıllarda J. Stalin başında bulunan Sovyet yönetimi tarafından uygulanan sanayileşme, kolhozlaştırma, göçebeleri yerleştirme ve sosyalist kültürü halka yayma faaliyetlerinin eksikliklerini görebilmiştir. Yazar günlüğünde üst düzey Sovyet devlet makamlarının yanlış yürüttüği politikaları çok olumsuz değerlendirmektedir.

Maalesef 1938 yılında Sovyet yönetiminin Türkistan'da kurulmasına ve pekiştirilmesine, rejimin siyasi, ekonomik ve kültürel kuruluşundaki önemli hedeflerin gerçekleştirilmesine bizzat katkı sağlayan büyük devlet adamı C. Abdrahmanov kendisinin de içinde bulunduğu sistemin kurbanı olmuştur. Çalışmada C. Abdrahmanov'un hayatı ve faaliyetleri üzerinde durulacaktır. Özellikle günlüğün içeriği analize edilerek diğer kaynaklardaki bilgiler ile kıyaslama yapılacaktır.

\section{Abdrahmanov'un Hayatı ve Faaliyetleri}

Sovyet dönemi Kırgızistan tarihinde tanınmış devlet adamı Cusup Abdrahmanov ${ }^{1} 28$ Aralık 1901'de Yedi-Su vilayeti, Karakol uezdinin² (günümüzde Isık-Göl bölgesi), Küngöy Aksu volostuna ${ }^{3}$ bağlı, Çirkey köyünde dünyaya gelmiştir. Varlıklı bir ailenin çocuğu olan Cusup Abdrahmanov, 1914'te Isık-Göl bölgesindeki Sazanov köyünde bulunan üç senelik Rus okulunu tamamladıktan sonra 1915'te Karakol şehrinde üst dereceli bir okula başlamıştır. Fakat Rus Çarlığına karşı 1916 Milli-Bağımsızlık Mücadelesinin patlaması üzerine ailesi ile beraber Çin'e sığınmaya mecbur kalır ve eğitimine devam edemez. O sırada 15 yaşında olan Cusup Abdrahmanov 1916 isyanında küçük kardeşi dışında anne babası ve kardeşleri olmak üzere tüm yakınlarını kaybeder. 1917 senesinde Çin'den dönen Cusup Abdrahmanov Karakol asker garnizonundaki Rus subayların atçısı, kapıcı olarak çalışıp

\footnotetext{
${ }^{1}$ Bilimsel araştırmalarda C.Abdrahmanov'un ismi Rusça tellafuza uygun olarak Yusup ya da Yusuf olarak da kullanılmaktadır. Bu makalede Kırgızca Cusup şeklinde yazmayı uygun bulduk.

2 Uezd: Rus Çarlığı döneminde ve Sovyet yönetiminin ilk yıllarında Türkistan'da vilayete bağlı günümüzdeki ilçe karşıllı̆ındaki idarî birimin adı.

${ }^{3}$ Volost: Rus Çarlığı zamanında ve Sovyet döneminin yerleşmesinden sonra kullanılan uezdden sonra en alt idarî yap1.
}

SEFAD, 2019; (42): 341-360 
geçimini sürdürür. 1918'de Ekim Devrimi sonrasında kurulan Kızıl Ordu'ya girer ve İç Savaş ${ }^{4}$ yıllarında Yedi-Su vilayetinde Sovyet yönetiminin kurulmasına katkı sağlar. 1919'da Almatı'da asker kursunda eğitim alır, aynı sene Rusya Komünist Gençler Birliği'nin (kısaltılmış şekli Komsomols) Türkistan Bürosu Başkanlığının ve aynı örgütün Yedi-Su Vilayeti Düzenleme Bürosu üyeliğine seçilmiştir. 1920 yılında Moskova'da düzenlenen Komsomol'un 3. Kongresi'ne Türkistan'dan murahhas olarak katılır ve proleterlerin lideri V. Lenin ile görüşüp fikir alışverişinde bulunur. 1920-1924 yılları arasında Türkistan Komünist Partisinin Almatı, Taldı-Korgon, Karakol şehir komitelerinde sekreter, Pişpek (günümüzde Bişkek) şehir ve Yedi-Su vilayet komitelerinde bölüm başkanı olarak çalışır. Mart 1924'te Türkistan Özerk Sovyet Sosyalist Cumhuriyetinin Merkezi İcra Komitesi kurul üyeliğine ve sekreterliğine tayin edilir. Mayıs 1925'ten itibaren Rusya Komünist Partisi ${ }^{6}$ Merkez Komitesi Orta Asya Bürosu'nda bölüm başkan yardımcısı, aynı sene Ağustos ayından başlayarak Moskova'da Rusya Komünist Partisi Merkezi Komitesinde memur görevlerinde bulunmuştur. 1927 yılında henüz 26 yaşındayken Kırgız Özerk Sovyet Sosyalist Cumhuriyetinin (Kırgız ÖSSC) Halk Komiserler Kurulu başkanlığına tayin edilir (KC SB MDA, fon.10, liste.15, dosya.22. C. Abdrahmanov'un şahsi dosyası: 3-14).

Kırgız ÖSSC Halk Komiserler Kurulu başkanı görevinde bulunduğu sırada dönemin şartlarına göre merkezden (yani Moskova'dan) bağımsız olarak olağanüstü cesurca bir politika yürütmüştür. 1933'te Stalin'in devlete tahıl teslim etmek talimatını yerine getirmediğinden dolayı Tüm Birlik Komünist Partisi üyeliğinden çıkartılarak görevinden azledilmiştir. O'nun görevinden alınmasını Sovyet yönetiminin günlüğü hakkında haberdar olması da olumsuz etkilemiştir. 1933-1935 yıllarında Rusya'nın Samara şehrinde yaşar ve Orta Volga bölgesinin hayvancılık şubesi bölüm başkan yardımcısı, 1935-1937'de Orenburg vilayet komitesinde hayvancılık şubesi müdür yardımcllığı görevlerinde çalışmıştır.

Cusup Abdrahmanov, Sovyet döneminde Kırgız devletçiliğinin temelini atan liderlerdendir. 1920'lerde Orta Asya'yı milli sinırlara bölme meselesinde her zaman Kırgızların menfaatini savunmuştur. Hatta tarihi ve kültürel bağlarıyla Kırgızlara akraba olan Karakalpakları birleştirilerek başkent Celal-Abad olmak üzere Isık-Göl'den Aral denizine kadar birleşik Kara Kırgız ve Karakalpak Özerk cumhuriyetinin teşkilini teklif etmiştir (Abducaparov ve Bekboyev, 2002, s. 25-26). 1921'de C. Abdrahmanov devlet adamları A. Sıdıkov, İ. Arabayev ile birlikte Kırgızistan'ın kuzeyinde Dağlı Kırgız Özerk Vilayeti kurulması projesi öne sürmüşlerdir. Bu proje ilk başta Mart 1922'de Türkistan Komünist Partisi Merkez Komitesi tarafından desteklenmesine rağmen SSCB üst yönetimi tarafından reddedilmiştir. C. Abdrahmanov, Kırgız millî devletini kurma yönünde teşebbüslerine devam etti ve 1924'te Kara Kırgız Özerk Vilayeti'nin kuruluşuna katkısı büyüktür. 14 Ekim 1924'te Orta Asya'yı millî cumhuriyetlere ve vilayetlere bölme projesi

\footnotetext{
${ }^{4}$ İç Savaş: $1917^{\prime}$ de yönetimi ele geçiren bolşevikler ve onlara muhalif olan güçler arasında 1918-1922 yılları arasında yapılan savaş.

${ }^{5}$ Komsomol: Rusçada Kommunistichesky Soyuz Molodyozhi kelimesinin kısaltmasıdır. Rusça tam adı VLKSM, yani Vsesoyuzny Leninskiy Kommunistichesky Soyuz Molodyozhi -Sovyetler Birliği Komünist Partisi Gençlik Örgütünün adidir.

6 1898'de teşkil edilen Rusya Sosyal Demokrat İşçi Partisi, 1917-1918 y1llarında Rusya Sosyal Demokrat İşçi Partisi (bolşevik) olarak adlandırıldı. 1918-1925 yıllarında ise partinin ismi Rusya Komünist Partisi (bolşevik) şeklinde kullanıldı. 1925-1952 tarihlerinde ise Sovyet cumhuriyetlerinin bir birliğe (SSCB) dahil edilmesinden dolayı Tüm Birlik Komünist Partisi (bolşevik) adına çevrildi. 1952'de Sovyetler Birliği Komünist Partisi olarak isim değiştirmiştir. Makalede 1917-1925 yılları arasında partinin kısaltılmış resmi adlarında parantez içinde gösterilen bolşevik tanımlaması kullanılmadı.
} 
çerçevesinde Kara Kırgız Özerk Vilayeti kurulmuştur. Kara Kırgız Özerk Vilayeti 1926 yılında Kırgız Özerk Sovyet Sosyalist Cumhuriyetine (Kırgız ÖSSC) dönüştürülmüştür. Cusup Abdrahmanov, 1929 ve 1930 yıllarında Tüm Birlik Komünist Partisi Merkez Komitesinin Genel Sekreteri J. Stalin'e iki defa mektup yazarak Kırgız Özerk Sovyet Sosyalist Cumhuriyetine bir üst statü olan tam yetkili Sovyetler Birliği cumhuriyeti statüsünün verilmesi meselesini dile getirmiştir. Stalin'e yolladığı bu mektuplar cevapsız kalsa da 1936 senesinde Kırgız Özerk Sovyet Sosyalist Cumhuriyetine Kırgız Sovyet Sosyalist Cumhuriyeti statüsü verilmiştir (Cunuşaliyev, 2002, s. 7-10).

Cusup Abdrahmanov, 4 Nisan 1937' de Orenburg şehrinde milliyetçi, pantürkist AlaşOrda örgütü üyesi, Kırgızistan'ı SSCB'den bölerek İngiltere ile birleştirmeyi planlayan karşı devrimci Sosyal-Turan partisiyle ilişkisinin olduğu suçlamasıyla tutuklanmıştır. Suçunu itiraf etmesi için Abdrahmanov'a daynılmaz çok ağır işkenceler uygulanmıştır. 5 Kasım 1938'de SSCB Yüksek Mahkemesi kararılla halk düşmanı olarak kurşunlanmak suretiyle ölüm cezasına çarptırılmıştır. 1958 senesinde SSCB Yüksek Mahkemesi tarafından aklanmıştır (Tursunov, 2001, s. 19-20). Sovyet Repressiya politikası tutuklanan kişilerin aile üyelerini ve çocuklarını da olumsuz şekilde etkilediği bilinmektedir. Abdrahmanov tutuklandıktan sonra eşi ve 5 çocuğu halk düşmanı ailesi olduklarından dolayı zor günler yaşamışlardır.

Sovyet döneminde uzun yıllar boyunca ismi bilinmeyen Cusup Abdrahmanov hakkında bilgiler ancak M. Gorbaçov'un başlattığı Perestroyka (Yeniden Yapılanma) zamanında (1985-1991) gün ışığına çıkartılmaya ve Kırgız toplumuna tanıtılmaya başladı. 1991'de Cusup Abdrahmanov'un cesedi Bişkek yakınındaki Çon-Taş köyü civarında Kasım 1938'de öldürülen 137 kişinin naaşının gizli gömüldüğü toplu mezarda bulunmuştur. Ağustos 1991'de cesetler tekrar toprağa defnedilmiş, bu yere Ata Beyit yani Atalar Mezarı ismi verilmiştir. 1991 sonrası Kırgızistan'ın egemenlik yıllarında Cusup Abdrahmanov'un hayatı ve faaliyetleri üzerine birçok bilimsel çalışmalar yayınlanmıştır. Bişkek şehrindeki büyük caddeye Cusup Abdrahmanov'un ismi verilmiştir. Bişkek, Karakol, Çolpon-Ata şehirlerinde ve doğduğu köyde Cusup Abdrahmanov'un heykeli yaptırılmıştır.

\section{Abdrahmanov'un Günlüğ̈̈}

Cusup Abdrahmanov Rus dilinde serbest okuyup yazabiliyordu. Aynı zamanda ana dili Kırgızcanın yanında, Tatarca, Özbekçe ve Kazakça gibi Türk lehçelerine de hâkimdi. Cusup Abdrahmanov devlet adamı özelliğinin dışında bir tarih meraklısı ve Sovyet döneminde ilk tarih eserleri yazarı olarak da bilinmektedir. C. Abdrahmanov Kırgız tarihi üzerine kapsamlı ve objektif şekilde araştırmalar yürütmüştür. Cusup Abdrahmanov, 1916 Milli-Bağımsızlık Mücadelesi tarihini ve 1917 Şubat ve Ekim Devrimlerinin bölgede kurulması dönemi olaylarını ve Sovyet yönetiminin ilk yıllarında Kırgızistan'ın durumunu ele alıp inceleyen araştırmacıdır. O, 1926 yılında 1916 Milli-Bağımsızlık Mücadelesi hakkındaki hacimli makalesini, 1928'de Kırgızistan tarihini içeren "Kırgızistan" eserini yayınlanmıştır. 1920-1930'lu yıllarda Kırgızistan'ın hayvancılık alanı üzerine de çalışmaları mevcuttur. Kendisinin yaşadığı dönemin olaylarına sadece şahitlik veya gözlemci olmanın dışında eserlerinde 1916'dan 1938 yılına kadar her olayı (1916 Milli Mücadele, Kırgızistan'da Sovyet yönetiminin kurulması, sosyoekonomik durum, eğitim ve kültür vs.) detaylı bir şekilde ele almış ve gerektiğinde kendi fikir ve önerilerini de belirtmiştir (Abdırakman Uulu, 2018, s. 3).

SEFAD, 2019; (42): 341-360 
Cusup Abdrahmanov Rusça kaleme aldığı gizli günlügünde ise şahsî görüşlerini kaydetmiştir. Günlük sayfalarından yazarın vatanı Kırgızistan ve halkının geleceği hakkındaki düşüncelerini, duygularını ve endişelerini okuyabiliriz. Cusup Abdrahmanov'un günlüğü 1928-1931 yılları arasında tutulan kayıtları içermektedir. Abdrahmanov'un bolşeviklerin lideri Lenin'den esinlenerek ismini verdiği kızı Lenina Abdrahmanova (1936-2017) bu günlüğü uzun ylllar muhafaza etti. Cusup Abdrahmanov aklandıktan sonra 1989'da günlük KGB tarafından kızı Lenina'nın eline verildi. Lenina Abdrahmanova Sovyet döneminde Frunze'de fabrikada çalışmıştır. C.Abdrahmanov Gülbahram adlı Kazak bir hanımla evlenip 5 çocuklu olmuştur. Ama günlüğünde bolşevik siyasetçi Lev Troçki taraftarı Mariya Natanson'a ${ }^{7}$ karşı aşk hislerini de açıkça yazmaktadır. Mariya Natanson sayesinde meşhur Rus şairi Vladimir Mayakovski (1893-1930) ve ailesi ile tanışıp onlarla dostluk ilişkilerini sürdürmüştür. Abdrahmanov Moskova'ya her iş seferinde V.Mayakovski ve başka dönemin önde gelen sanatçı, edebiyatçı ve aydınların toplantılarına katılıyor, müze ve tiyatroları ziyaret ediyordu.

Abdrahmanov'un günlügünden alıntılar ilk defa Kırgızistan'da 1989 yılında “Literaturnıy Kirgizstan" dergisinde yayınlanmıştır. 1991'de C. Abdrahmanov'un günlüğü ve diğer eserleri Kırgızstan yayınevi tarafından "1916. Dnevniki. Pisma k Stalinu. (1916. Stalin'e Mektuplar)" adı altında Rusça kitap halinde tarihçiler C. Cunuşaliyev ve İ. Semenov'un giriş yazısıyla yayınlanmıştır. 2013'te Rusça ikinci baskısı basılmış, 2016 yılında ise Uluu Toolor yayınevi tarafından Kırgızca çevrilen baskısı basılmıştır.

C. Abdrahmanov günlüğünü 18 Ağustos 1928 tarihinde Moskova'da bulunduğu sırada kaleme almaya başlamıştır. Yazarın ilk günkü ifadeleri aşağıdaki gibidir:

"Kaderin isteğiyle, en büyük tarihi dönemin olaylarına şahit oldum. Bu nedenle, birisinin her gün için gördüklerini, yaşadıklarm ve hissettiklerini kaydetmek tarih için önemlidir. Bu bir günlük yardımı ile yapılabilir ve ben bunu yapmaya çalışacă̆ım. Doğru, bunu büyük bir gecikmeyle yapıyorum, ama geç olması hiç olmamasından daha iyidir.

Benim günlüğ̈̈m... Sen bundan sonra benim tek, sadık ve sessiz arkadaşımsın. Benim elimde olduğun sürece sen bana sadıksın, başkalarının eline geçtiğin zaman hain olabilirsin, böyle bir ihtimal de yüksektir, ama yine de ben senden hiçbir şey gizlemeyeceğim. Ben sana sadece devlet adamının değil, sıradan bir kişinin düşüncelerini ve deneyimlerini de aktaracă̆ım.

Benim arkadaşım! Ben sana aktardıklarımı ben hayatta olduğum sürece sen kimseye söylememelisin, ben öldükten sonra istediğin kişiye, istediğin şekilde söyleyebilirsin. Böylece düşüncelerimi dinle, ne olduğu ve ne olacă̆̆ hakkında hikâyelerimi dinle" (Abdrahmanov, 1991, s. 95).

C. Abdrahmanov devlet adamı olmasindan dolayı 1920-1930'lu yıllarda kolhozlaştırma, sanayileşme, Kırgızların yerleşik hayat tarzına geçirilmesi, Sovyet Kültür Devrimi gibi o dönemdeki başlıca sosyalist düzenlemelerin uygulama süreçlerine direk

\footnotetext{
7 Mariya Yakovlevna Natanson (1901-1938): 1917 Ekim İhtilaline gönülden inanarak aynı sene Rusya Sosyal Demokrat İş̧̧i Partisi üyesi olmuştur ve Leningrad'da parti işlerinde görev alır. 1927'de Komünist parti üyeliğinden çıkartılıp Orta Asya'ya sürgün edilmiştir. Bir süre Kırgız Sovyet Sosyalist Cumhuriyetinin başkenti Frunze'de iktisatçı olarak çalışan Mariya 1928'de Leningrad şehrine döner yarıda bıraktığı Leningrad Elektroteknik Enstitüsünden mühendis elektrik uzmanlığında eğitimini 1930'da tamamlar. Mariya Natanson 1935'te Troçkist suçlamasıyla tutuklanıp Sovyet kamplarında kaldıktan sonra 1937'de kurşunlanır.
} 
katılmıştır. Ve günlüğünde onlar hakkında fikirlerini serbestçe kâğıda dökmüş ve çoğu zaman Sovyet yönetiminin sosyalist faaliyetlerini ve uygulamadaki zorlama yöntemlerini eleştirmiştir.

Bolşeviklere göre Sovyet toplumu proletarya ve burjuvaziden oluşan birbirine zit iki kampa ayrılıyordu. Bu sebeple Sovyet yönetiminin burjuvazi olarak görülen varlıklı kesime karşı mücadele ettiği bilinmektedir. Cusup Abdrahmanov ise varlıklı tabakadan gelen manap 8 ailesinde doğup büyümüştür. Bu sebeple $\mathrm{O}, 17$ Ocak 1931 tarihinde yazdığ günlüğünde "Doğuştan bir adam değil, yaratılan adam olduğunu, kendi kendisini yaratan kişi olduğunu, 1917 Sosyalist Devrime başka düşman bir kamptan geldiğini, yani manabın oğlu" olduğunu açıkça yazmış olduğu bu satırlarla devam etmektedir: "Sovyet yönetimine dürüstçe katıldım, ancak şimdi bilinçli bir şekilde katılmadığımı düşünüyorum. Kendi geçmişim ve günümüzdeki durumum arasında 14 ylllı mücadele beni devrimin iyi bir askeri yaptı, ancak ortaya çıktığına göre bu yıllarda süren mücadele beni tam bir bolşevik yapmadı. Yoksa ülkemdeki her türlü küçük başarısızlıklara karşı çok sancılı tepki gösterdiğimi başka türlü nasıl açıklayabilirim?" (Abdrahmanov, 1991, s. 150).

Cusup Abdrahmanov varlıklı bir yönetici aileden gelmesine karşın ilk başta yeni rejime gönülden inanarak Komünist Partinin iyesi olmuş, kısa sürede kendisini üst düzey devlet adamı olarak yetiştirebilmiştir. Cusup Abdrahmanov çok iradeli ve çalışkan birisi idi, günlügünde çoğu zaman iş yerinde gece saat 12.30 'a kadar çalıştığını belirtmektedir. $O$, Kırgızistan'ın çeşitli sorunlarını gidermek için çok gayret etmiştir. Fakat günlük sayfalarından anlaşılacağı üzere her zaman da kendinden memnun değildi, halkı için çok az çalıştı̆̆ını, bazen çabalarının başarıya ulaşmadığını düşünüyordu. Gizli kaleme aldığı günlüğünde birçok arkadaşı olmasına rağmen aslında yalnız olduğunu ve genellikle kendisini yalnız hisettiğini yazmaktadır.

\section{Abdrahmanov'un Günlügünde Kırgızistan'ın Sosyoekonomik Tarihiyle İlgili Bilgiler}

Cusup Abdrahmanov, 1927-1933'te Kırgız Özerk Sovyet Sosyalist Cumhuriyetinin Halk Komiserler Kurulu başkanı görevinde çalıştığı yıllarda Kırgızistan'ın sosyoekonomik durumunun iyileşmesine gayret etmiştir. Cumhuriyette sanayi fabrikalarının, kara ve demir yollarının kuruluşu, otomobil araçların ulaştırılması, orduda Kırgız ulusal alayların teşekkülü, sağlık personelleri ile sağlamak gibi başka pek çok konuyu bölgesel Orta Asya Bürosu ve Moskova'daki üst yönetime bildirerek gündeme getirdiğini günlügüunde belirtmektedir.

1927 yılının sonunda SSCB çapında görülen tahıl kıtlı̆̆ı yüzünden yüksek yönetim tarafından fakir köylülere dayanarak zengin ve orta halli köylülere baskı yapılmaya başladı. Köylüler ürettikleri tahılı ucuz ve sabit fiyata devlete teslim etmekte zorlandılar. Bu taleplere uymadıkları zaman onları hapsetme, arama yapma ve şiddet hareketleri yaygınlaştı (Viola, 2007, s. 16). 1928'de tahıl hazırlama krizini atlatmak için ucuz ürünleri üreten kolhoz ve sovhoz adlandırılan devlet çiftliklerinin rolleri güçlendirildi. Hızlı bir şekilde kolhoz ve sovhozlar kuruldu (Cumanaliyev, 2005, s. 261). 1929-1930 yıllarında Kırgizistan'da 2749 $k_{\text {ulak }}^{9}$ çiftliğine tahıl hazırlama planı uygulanarak her birine ortalama 220 pud ${ }^{10}$ payı

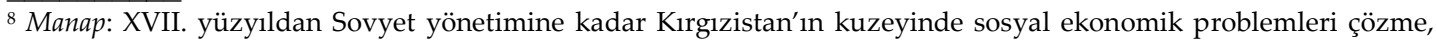
yargılama yetkisine sahip, yönetici boy başkanının unvanıdır.

${ }^{9}$ Kulak: Zengin köylü anlamındadır.

${ }_{10}$ Pud: 16,38 kiloya eşit ağırlık birimi.
}

SEFAD, 2019; (42): 341-360 
düşmüştür. (Asanbayev, 1968, s. 61). Ürettikleri tahılı zamanında teslim etmeyenlere, teslim etmesi gereken ürün miktarının 4-5 katını ödemeye zorlama gibi cezalar verilmiştir (KC SB MDA, fon.10, liste.1, dosya. 203: 27-28).

Tarımın ortak işletildiği kolhozlara üye olarak girmek herkesin kendi isteğine göre gönüllü yapılması gerekiyordu. Fakat kolhoz uygulamasına karşı çıkan köylülere şiddet ve korkutma yöntemi kullanılmıştır (Cunuşaliyev, 2003, s. 160-164). Kolhozlaştırmaya göre halkın elindeki toprak, tarım aletleri ve hayvanlar devletleştirilecekti. Zorla kolhozlaştırma faaliyeti hayvancılığın büyük zarar görmesine de neden olmuştur. Bolşeviklerin kolhozlaştırma tehdidi altında köylüler hayvanlarını kesip veya satıp yok etmeye başlamışlardır. 1928'de Kırgızistan'da toplam hayvan sayısı 7715 baş iken, 1934 yılının başına doğru bu sayı 2100'e, yani \%73 oranında azalmıştır (Baktıgulov, 1990, s. 88).

Devlet makamları tarafından köy hanelerinde gayriresmi arama ve müsaderelerin yapılması, kolhozlaştırmadaki tahrifatlar ve keyfî hareketler Abdrahmanov'da protest bir tepki yaratmıştır. Cusup Abdrahmanov tahıl, pamuk ekimi, hayvan yetiştirme, yün hazırlama başka ağır devlet görevlerinin orta halli çiftliklere uygulanmasını, köylülerin kolhoz ve sovhoz gibi devlet çiftliklerine alınma sürecindeki şiddetli baskı yöntemlerini kınamıştır. O, Stalin'in bu tür zorlama siyasetini sosyalist kuruluşta Lenin prensiplerinin bozulması olarak değerlendirmiştir. 1 Eylül 1928 tarihli günlüğünde Sovyet yönetimi tarafından köylülere yönelik uygulanan baskılardan dolayı üzülmektedir. 30 Temmuz, 1930 tarihinde ise dağllk bölgede dinlendiği zaman insanların kolhoz, hayvanlar, Sovyet yönetimi hakkında konuştuklarını, Sovyet yönetiminin iyi olduğunu fakat aynı zamanda sefalet getirdiğini belirttiklerini günlügünde kaydetmektedir. Kendisinin üç çiftliğe denetim yaptığı zaman hayvanların 1/3'inin kesilerek yok edildiğini yazmaktadır (Abdrahmanov, 1991, s. 99183).

1930 yılının sonbaharında Moskova' daki SSCB üst yönetimi Taşkent'te bulunan Orta Asya Bürosu'na Orta Asya en az 28 milyon pud pamuk üretip devlete teslim etmesi hakkında direktif yollamıştır. Planı yerine getirmek için tüm Orta Asya çapında köylülere baskılar ve haneleri aramalar başlatılmıştır. Pamuk coğrafî şartlardan dolayı Kırgızistan'ın güneyinde yetiştiriliyordu. Cusup Abdrahmanov söz konusu planın icrasının imkânsız olduğunu yazmaktadır.

\footnotetext{
“26 Aralık 1928. Celal-Abad. Pamuğun \% 100 toplanmayacă̆ı açıktır. Devletin hiç bir emri burada yardımcl olamaz. Bizim yöneticiler hangi vücut bölümü ile düşünüyorlar, bilmiyorum. Fakat onların direktifleri ileri görüşlü politikacılarm direktifleri değildir. Evlerde müsaderelerin yapılması, kolhozculara yönelik baskılar vb. olaylarm hepsi köylülerin gözünde devlet otoritesini düşürecektir" (Abdrahmanov, 1991, s. 136).
}

1931 yılının Ocak ayında Kırgızistan'ın güney bölgesindeki köyleri gezdiği sırada Orta Asya Bürosu'nun arama yapılması hakkında direktifine rağmen kendilerine düşen devlet görevlerini dürüstçe yerine getiren orta çiftliklerin evlerinde arama yapmamıştır. Köylülerin pamuk üretimi ile uğraşmayı kendilerine gerekli bir üretim olarak değil, devlet görevi olarak algıladıklarını, bu sebeple ilgi göstermediklerini üzülerek belirtmektedir (Abdrahmanov, 1991, s. 143). 
1920'li yılların sonlarına kadar Sovyet hükümeti tarafından "Sinıf Mücadelesi"11 siyaseti ışığında varlıklı kesimi seçim hakkından mahrum bırakmak, aşırı vergi ödemek, tarımda ve hayvancllıkta ağır devlet görevlerini yerine getirmek suretiyle kısıtlama siyaseti yürütülmüştür. Daha sonra tüm Sovyetler Birliğinde topyekûn kolhozlaştırmanın temelinde "Kulaklar sınıf olarak ortadan kaldırmak" faaliyeti ilan edildi. "Kulaklarn sinıf olarak ortadan kaldırmak" zengin kesimin mal ve mülklerinin devlet adına müsadere edilmesi ve SSCB'nin uzak bölgelerine sürgün etmek anlamına geliyordu (Viola, 2007, s. 6-7).

Kırgız toplumu da zengin-fakir olarak iki sınıfa ayrılmıs ve varlıklı tabaka sayılan baymanaplar12 kulaklar kategorisine eklenmiştir. "Kulakları sinıf olarak ortadan kaldırmak" çerçevesinde Kırgızistan'dan da varlıklı insanları diğer Sovyet cumhuriyetlerine zorla göçürme yöntemi uygulanmıştır. 1927 ve 1932 yılları arasında bay-manaplar toplu halde Kırgızistan'dan Rusya, Ukrayna gibi uzak yerlere sürgün edilmiştir (KC SB MDA, fon. 10, liste. 1, dosya. 363: 71-72). Sürgün edilenlerin özel mülkleri kolhozlara aktarılmıştır. Diğer Sovyet Cumhuriyetlerinde de görüldüğü gibi, Kırgızistan'da da kulakları sosyal bir sinıf olarak bütünüyle ortadan kaldırma politikası sırasında aşırılığa kaçılması sonucu sadece varlıklı tabakalar değil, yüzlerce orta çiftlikler hatta fakir kesim bile zarar görmüşlerdir.

Cusup Abdrahmanov varlıklı tabakaların kolhozun faydasına özel mülklerinin hemen ellerinden alınmasının taraftarı değildi. Ona göre önce göçebe bölgelerde fakirlerle işbirliği yöntemlerini belirlemek ve onların ekonomik hayatını düzenlemek gerekiyordu, bunları yapmadan varlıklı çiftliklerin hayvan ve mülklerinin müsaderesi olumlu sonuçları getirmeyecekti. Bay-manaplar konusunda onlarla mücadele edilmesini, yerli Sovyet yönetimi üzerinde onların etkisini yok etmeyi desteklemektedir. Fakat onların uzak diğer Sovyet cumhuriyetlerine göçürülmesinin pek gerçekçi olmadığını, çünkü boylar temelinde birleşen Kırgız halkının gözünde aksine onların itibarını arttıracağı fikrini ileri sürmektedir. Zenginlere yönelik yapılan ekonomik kısıtlama ve tedbirlerin hiç bir şekilde orta çiftliklere ve fakir kesime uygulanmaması gerektiğinin altını çizmektedir (Abdrahmanov, 1991, s. 206).

Günümüzde Sovyet arşiv belgelerinin detaylı analizi Cusup Abdrahmanov'un haklı olduğunu göstermektedir. Arşiv belgeleri sıradan halk "sınıf mücadelesi" çerçevesinde baymanapların mülklerine el konulması ve sürgün edilmelerini kendi boylarına zarar olarak kabul ettiklerini ve Sovyet yönetimini değil, onların taraflarını tuttuklarını kanıtlamaktadır (KC SB MDA, fon. 10, liste. 1, dosya. 201: 29; dosya. 201: 33-34).

Sovyet plânına göre, göçebeleri yerleşik hayata geçirme, kolhozlaştırmayı güvence altına alacaktı. Bu sebeple 1931 ve 1941 yılları arasında göçebe Kırgızları yerleşik hayat tarzına geçirme faaliyeti gerçekleştirilerek yeni köyler ortaya çıkmıştır (Baktıgulov, 1971, s. 60). Yerleşik hayata geçirilen Kırgızlar, 1931-1934 yıllarında kitle halinde kolhozlara girmeye mecbur tutulmuşlardır. Halkı yerleşik hayata geçirme sırasında birçok yerde ciddî eksiklikler ve hatalar yapılmıştır. Nitekim bazen yeni yerleşim yerlerinin seçimi doğru yapılamamış, tarıma elverişsiz, hayvanlara yem hazırlamaya imkânsız, susuz yerler

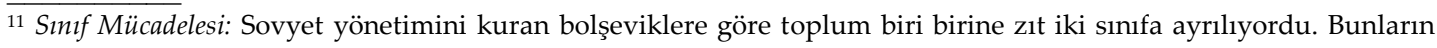
birisı proletarya, ikincisi burjuvazi idi. Sanayide çalışan işçiler ile kırsal kesimlerde tarımla uğraşan topraksız köylüler proletarya sınıfını oluşturuyordu. 1917 Ekim Devrimine kadar toplumda aristokrat kabul edilenler, tüccarlar, kulak adlandırılan varlıklı çiftlikler burjuvazi sınıfındaki kapitalistler olarak bakılmıştır. (Fitzpatrick 2005:32).

12 Bay-Manap: Kırgız Türkçesinde «zengin» anlamındaki bay kelimesi varlıklı sosyal tabakayı kastetmektedir. BayManap Sovyet döneminde genellikle sınıf düşmanları kategorisindeki zengin kesim anlamında birleşik kullanılmıştır.

SEFAD, 2019; (42): 341-360 
seçilmiştir. Bazı ilçelerde yerleşik hayata geçirme cereyanı hızlandırılarak yerleşik hayata geçmeyi istemeyen kişiler kolhozlardan çıkartılıp takibe alınmışlardır (Baktıgulov, 1990, s. 88). Cusup Abdrahmanov yerleştirme faaliyetinin hızlandırılmasını tenkit etmektedir. Örneğin, 1932 yılında Kırgız ÖSSC'de 30 bin haneyi yerleşik hayat tarzına geçirme planlanmış, Moskova yönetimi tarafından bunların 10 bininin onaylanmasına rağmen Kompartinin Kırgız Vilayet Komitesinin çok kısa zamanda tekrar 30 bin haneyi yerleştirme çabalarını ve hastane, okul, ev yapımında inşaat çalışmalarının aksadığını eleştirmektedir (Abdrahmanov, 1991, s. 298-302).

C.Abdrahmanov 1925 te Tüm Birlik Komünist Partisinin XIV. Kongresinden sonra yoğun bir şekilde uygulamaya konulan sanayileşme programına farklı yaklaşımda bulunuyordu. $\mathrm{O}$, Sovyet yönetiminin tarımda üretilen buğdayı yabancı devletlere satarak sanayiyi geliştirmeye gerekli parayı elde etmeyi planladığı şekilde köylülerin üzerinden hızlı sanayileşme taraftarı değildi. J.Stalin'in başında bulunan Sovyet yönetimi tarafından sanayileşme sürecinde göz yumulan hatalara ve aşırılığa kaçırılmasına kaygı duymaktadır.

“6 Kasım 1932. Ekmeksiz kolhozclar ve Dinyeper Hidroelektrik Santrali, Magnitogorsk, ${ }^{13}$ fakir Kazaklar, ve başkaları. Biz köylülerin büyük bölümünün ve işçi sınıfının belli bir kısmının maddî durumunu kötüleştirme hesabından çağdaş teknoloji ile donatılan büyük endüstriyi kurduk. Bu endüstri önümüzdeki 2-3 yıl içinde adı zikredilen tabakaların maddı durumların iyileştirmeye temel olabilecek mi acaba?" (Abdrahmanov, 1991, s. 188).

1927-1933'te Halk Komiserler Kurulu başkanı görevinde çalışttğ 1 yıllarda Cusup Abdrahmanov'un inisiyatifi sayesinde Kırgız ÖSSC'de birçok sanayi fabrikaları, demir yolları kurulmuştur. Hükümet başında bulunduğu devlet adamı olarak Kırgız ÖSSC'nin birinci beş senelik planını çok gerçekçi ve eleştirel tarzda değerlendirmiştir. $O$, sanayileşme programını gerçekleştirme sürecini sadece fabrikaların kurulması ve sayısının artması olarak değerlendirmemiştir. Cusup Abdrahmanov yeni fabrikaları kurarken SSCB cumhuriyetlerinin bölgesel özelliklerini ve ihtiyaçlarını, tarihsel koşullarının mutlaka göz önüne alınması gerektiğini savunmuştur. Günlüğünden de görüldüğü gibi Cusup Abdrahmanov bölgelerde yeni kurulan sanayi fabrikalarının aracılığıyla aynı zamanda o bölgelerin ekonomik ve sosyal problemlerini de çözmeye çalışmıştır.

Bu dönemde sanayi fabrikaları, demir yolları, enerji santrallerinin kurulması, tarım aletleri ve makineleri tahsisi üzerine Kırgızistan'ın bütçe planlaması merkezde ele alınarak onaylandığı için Moskova'ya defalarca giderek bu konularda Kırgızistan'ın menfaatini savunmuştur. Sanayileştirmeyi gerçekleştirme sürecinde Moskova'dan milli bölgelere maddi destekleri ayırmada eksikliklere göz yumulduğuna işaret etmektedir. Günlüğünden de anlaşılmak üzere Cusup Abdrahmanov Frunze (günümüzde Bişkek) ve Tokmok şehirlerini bağlayan demir yolu hattını kurmaya çok enerji ve emek harcamıştır. Bu, cumhuriyette şeker endüstrisinin yaratılması ve sonraki yıllarda bütün Çüy vadisinin ekonomisinde önemli bir yeri olan şeker pancarı üretimi ile ilişkiliydi. Aynı zamanda Tokmok-Rıbaçye demir yolu hattını planlamış bu konuyla ilgili 16 Nisan 1931'de Taşkent'e gittiği zaman Merkez Komitenin Orta Asya Bürosu'na başvurmuştur ama demiryolu malzemeleri olmadığından dolayı önerisi kabul edilmemiştir. 28 Nisan 1931 tarihinde ise Oş

13 SSCB'de Dinyeper Hidroelektrik Santrali ve Magnitogorsk Metalurji Tesisi ilk beş yıllık plan (1928-1932) döneminde yapılması planlanan en önemli büyük inşaatlar idi. 
şehrinde bulunduğu sırada Kara-Su-Oş demir yolu yapımının ertelendiğine ilişkin haberi aldığında bunu anlayamadığını, bu durumun azınlık milletlerin emekçi halkında Sovyet yönetimine yönelik olumsuz fikirlere yol açacağını belirtmektedir (Abdrahmanov, 1991, s. 165-169).

\section{Abdrahmanov'un Günlüğünde Kırgızistan'ın Kültür Tarihi Meseleleri}

1920-1930'lu yıllarda SSCB'de sanayileşme ve tarımı kolhozlaştırma ile eş zamanlı olarak Kültür Devrimini icraata geçirmeyi planlanmıştır. Kültür Devrimi bağlamında sosyalist kültürü yerleştirmek, halkın bütününü okuryazarlık seviyesine ulaştırmak, bilim, edebiyat ve sanatı geliştirmek amaçlanmıştır. Bu dönemde Kırgızistan'da Kültür Devrimi çerçevesinde alfabe değişikliği yapılmıştır. 1927'de o zaman kadar kullanılan Arap alfabesinin yerine Latin alfabesinin uygulanması yönünde karar alınmıştır.

C.Abdrahmanov yüksek devlet makamlarında çalıştığı zaman Kırgızistan kültürünün gelişmesi için birçok faaliyet gerçekleştirmiştir. 1920-1930'lu yıllarda Kırgızistan'ın doğası, yer altı kaynakları, sosyoekonomik yapısı, tarihi araştırılmıştır. 1927'de ünlü şarkiyatçı V. Bartold tarafından "Kırgızlar" adlı eserin kaleme alınmasında Cusup Abdrahmanov'un katkısı büyüktür. Sovyet Kırgızistan yönetimi Kırgızların tarihinin yazılması için V. Bartold ile görüşme yapmıştır. V. Bartold 1927'de tamamladığı "Kırgızlar"adlı eserinde farklı kaynaklarda yer alan Kırgızların tarihi üzerine temel bilgiler ilk defa sistemleştirilmiştir. Aynı dönemde Kırgız halk bilimi materyalleri toplanmıştır, Kırgız profesyonel edebiyatı gelişmiştir. Kırgızca bilimsel ve ders kitapları çoğaltılmış, ilk defa Kırgızca süreli yayınlar yayın hayatına başlamıştır. Sovyet tarzında eğitimin verildiği kreşler, meslek okulları, orta ve yükseköğretim kurumları, sanat okulları, müzeler, tiyatrolar açılmıştır.

Bir idareci olarak Cusup Abdrahmanov bölgeleri devamlı ziyaret ederek durumu yakından takip etmiştir. Gerektiği zaman sıradan bir insan olarak halkın içine karışmış ve onların şikâyetlerini dinlemiştir. Bu şikâyetler karşısında ise çok üzüntü duyguğunu belirtmektedir. Örneğin 1 Mayıs 1931 tarihinde Alay ilçesinin merkezi Gülçö’deki durumu gözlemlemek üzere burayı ziyaret etmiştir. 40000 nüfuslu ilçede tek bir doktorun bile olmadığı, yaklaşık 2600 baş hayvana bakacak veteriner doktorun bulunmadığı, 22.000 hektar alanda yetiştirilen tahıl ürünlerini inceleyecek ziraatçının bulunmadığı, ilçedeki 10 ortaokulda sadece 12 öğretmenin bulunduğu, onlardan sadece birinin orta eğitimli olduğu, halkın \% 95'inin okuryazar olmadığı, okuryazar olanların \% 5'inin de yeni Latin harflerinde değil, sadece eski Arap harflerinde yazılanları okuyabildikleri şeklinde buradaki gözlemlerini dile getirmiştir. Aynı ilçede yaşam şartlarının iyi olmadığını belirterek, insanlardan çalışmaları talep edilmektedir, netice itibariyle insanlara yaşam için gerekli asgari koşulların bile sağlanmadığı sonucunu çıkarmaktadır (Abdrahmanov, 1991, s. 170).

Günlüğünde o dönemde Kırgızistan'da çalışan birçok devlet adamı ve onların özellikleri de belirtilmektedir. Ayrıca 26 Ekim 1932 tarihinde Moskova'dan Kırgizistan'a tayin edilen bazı yöneticiler hakkında onlar için şahsî menfaat ve kariyerlerinin önemli olduğunu, Kırgızistan'ın ise sadece bir kariyer merdiveni olarak görüldüğünü eleştirmektedir. Böyle yöneticileri de günlüğünde Komünist Parti üyeliği olan kolonizatörler olarak adlandırmaktadır (Abdrahmanov, 1991, s. 111, 188). Gerçekten de 1920-1930'lu yıllarda Moskova'daki Komünist Partisi Merkez Komitesi bölgelere yetenekli devlet memurları gönderme gerekçesi ile Türkistan'a Rus asıllı bürokratları gönderme siyaseti takip edilmiştir. Örneğin 1925-1932 yılları arasında Kırgızistan'a genellikle Rus ve Yahudi asıllı 500'den fazla devlet memuru gönderilmiştir. Bunların çoğu Kırgızistan'ın sosyal ve 
ekonomik kalkınmasına katkı sağlamışlarsa da bazı idareciler için taşra görevleri, politik kariyer aracı olarak kullanılıyordu. Bu valiler, bölgenin şartlarını ve yerli halkın dilini, gelenek, görenek ve kültürüyle ilgili temel bilgilerden yoksundu. Genellikle onlar bölgenin değerlerini dikkate almadan komünizmin sınıf mücadelesi anlayışı doğrultusunda hareket ediyorlardı. (Cunuşaliyev, 2003, s. 79). Bu sebeple C. Abdrahmanov günlüğünde ulusal sektörün çıkarlarını göz ardı eden bazı Rus yöneticilere kızarak onların hareketlerini şovenizm, Rus milliyetçiliği olarak değerlendirmektedir.

O, cumhuriyetin resmî yazışma dilinin Kırgızca olması gerektiğini savunmuştur. Günlüğünde Kırgızistan'da Kırgızca belgelerin geçerli olmadığını ve her yerde Rusça belgeler istendiğini belirtmektedir (Abdrahmanov, 1991, s. 144). Maalesef günümüzde de bağımsız Kırgızistan'da büro işlerinde Kırgız dilinin kullanımı çok yetersiz kalmaktadır. Aşağıda günlügünden yine bir örnek verelim;

“26 Ocak 1931. Birçok ilçelerde Rus nüfus bulunmamaktadır. Ama bu ilçelerin devlet makamlarnda Kirgizca bilmeyen Rus görevliler oturmaktadirlar. Bu devlet memurlarn yüzünden ilçe makamlarmmn yazı işleri her zaman Rus dilinde yürütülmektedir. Demek ki ilçe yönetimi halk için değil, bu memurlar için çalışmaktadır" (Abdrahmanov, 1991, s. 153).

Cusup Abdrahmanov sosyalizmi inşa sürecinde yönetim kademelerinde çalışacak Kırgız gençlerinden oluşan kabiliyetli ve eğitimli millî kadroları yetiştirmeye önem veriyordu. $\mathrm{O}$, eğitimine ve yeteneğine göre kadroların seçilmesini savunmuştur, ancak o dönemde üst düzey devlet makamları tarafından sorgusuz bir şekilde her şeyi yerine getiren kadroların seçilmesini ve aynı zamanda dalkavuk devlet memurlarının çoğalmakta olduğunu eleştirmektedir. 1930 yılında cumhuriyetin uzak ilçelerini gezdiği sırada "yerli devlet personellerin ne yapacă̆ın bilmeden, kendi inisyatiflerinden yoksun, sadece yukarıdan emirlere göre makine gibi çalıştıklarına" şahitlik etmiştir (Abdrahmanov, 1991, s. 137).

\section{Abdrahmanov'un Kırgızistan'daki Siyasi Durum Hakkındaki Gözlemleri}

Cusup Abdrahmanov günlügünde 1920'li yılların ikinci yarısı ve 1930'lu yılların başında Kırgızistan'ın güney bölgesinde tekrar ortaya çıan Basmacı Hareketi ${ }^{14}$ hakkında da bilgileri sunmaktadır. Özel mülklerin müsaderesi, zengin kesimin oy kullanma hakkından mahrum bırakılması, onlara fazla vergi uygulanması ve devlet tarafından hayvan yetiştirme, yün hazırlama, ekin ekme gibi ağır yükümlülüklerin getirilmesi, insanların kolhozlara girmelerinde baskı yapılması gibi sebepler bu dönemde basmacıların yeniden silâhlı direnişine yol açmıştır (KC SB MDA, fon.10, liste.1, dosya. 253: 195). Güneydeki birçok ilçelerde adı geçen hareketin geniş çapta yayılmasından dolayı Sovyet yönetimine karşı gerginliğinin arttı̆̆ görülmüştür (Oş Bölgesel Devlet Arşivi, fon.1, liste 1, dosya. 298: 11; KC SB MDA, fon.6, liste.1, dosya. 30: 24; fon.10, liste.1, dosya. 229: 134).

15 Nisan, 1931'de Celal-Abad bölgesine bağlı Suzak köyünde bulunduğu sırada Cusup Abdrahmanov'a GPU'nun ${ }^{15}$ gönüllü asker birliğinin komutanı Klimov halkın kendi

\footnotetext{
$\overline{14}$ Basmacı Hareketi 1918'de Türkistan'da Sovyet yönetimine karşı ortaya çıkmıştır. 1923-1924 yıllarında Kızıl Ordu tarafından Orta Asya'da basmacıların büyük bölümü ortadan kaldırılmıştır. Kırgızistan'da 1924'ten 1934 yılına kadar basmacılar küçük gruplarla dağlık bölgelerde Sovyetlere karşı mücadeleye devam etmelerine karşın ayaklanma başarısız sonuçlanmıştır.

15 GPU: Rusça'dan tam adı Gosudarstvennoye Politiçeskoye Upravleniye, Devlet Siyasî Başkanlığı. SSCB'de 1922'de kurulan devlet karşıtı siyasî ve ekonomik faaliyetleri önlemek, bastırmak, devlet güvenliğini sağlamak görevini yürüten kurum.
} 
birliğine yardım etmediklerini şikâyet etmiştir. Bu arada Suzaklı 6 kişi (onlardan biri kolhoz üyesiydi) gönüllü olarak basmacılara katıldıklarını Abdrahmanov yazmaktadır. 24 Nisan 1931 yılında ise Celal-Abad şehrinde bulunduğu sırada Celal-Abad'dan 7 kilometre uzak mesafede Özbek basmacıların mücadele ettiklerini ve Kırgızların da onlara katıldıklarını öğrendiğini belirtmektedir (Abdrahmanov, 1991, s. 167). Sovyetlerin uyguladığı sert politikalar yüzünden gerçekten de Kırgizistan'ın güneyinde basmacı kolları sıradan halk içinde büyük bir destek görmüştür ve hareket üyelerinin sayısı artmıştır (KC SB MDA fon.10, liste.1, dosya. 281: 20,114; Oş Bölgesel Devlet Arşivi, fon. 79, liste.1, dosya. 14: 63-67).

1920'li yılların sonu ve 1930'lu yılların başında Kırgızistan'ın güneyinde özellikle Canıbek Kadı'nın ${ }^{16}$ yönettiği basmacı kolları ile Kızıl Ordu arasında çetin çatışmalar yaşanmıştır (KC SB MDA, fon.10, liste.1, dosya. 203: 41). Cusup Abdrahmanov da Canıbek Kadı'nın memleketi Özgen'in “Basmacı hareketinin kalbi ve o dönemdeki basmacı hareketine katılan kahramanların memleketi olduğunu, Özgen sakinlerinin yeni oluşacak basmacı kollarına katılabileceklerini" günlüğünde belirtmiştir (Abdrahmanov, 1991, s. 144).

Cusup Abdrahmanov günlüğünde Sovyet yönetimi tarafından yürütülen ağır siyasiekonomik politikaların Basmacı Hareketinin güçlenmesine zemin hazırlayacağını tahmin etmektedir. 23 Aralık 1930'da Cusup Abdrahmanov tahıl ve pamuk üretip bu ürünlerin devlete tesliminde köylülere baskı uygulanmasının basmacı askerlerinin sayısının arttıracağı ihtimalinin çok yüksek olduğunu belirterek bu durumdan dolayı endişe etmektedir. 13 Ocak 1931 yılında ise güney bölgesinde iş seyahatinde bulunduğu esnada kapalı asker giyimiyle gizlice Oş, Celal-Abad ve Kara-Su şehirlerindeki pazarları ve birçok çayhaneleri gezdiğini, sıradan halkın konuşmalarını dinlediğini ve devlet uygulamalarına karşı büyük hoşnutsuzluk olduğunu belirtmektedir. Abdrahmanov köylülere onların imkânlarından fazla vergi ve ürün teslimi uygulanmasının yanlış olduğunu ve tanık olduğu böyle konuşmaların basmacı isyanlarının bahar aylarında yeniden ortaya çıkma olasıllğı hakkındaki endişelerinin tamamen doğruladığını belirtmektedir. Cusup Abdrahmanov'a göre Basmacı Hareketini önlemek için bu direnişin yayıldığı göçebe ve yarı göçebe ilçelerde yaşayan halka ekonomik ve kültürel hizmetleri sağlama problemlerini çözmek ve oralara yeterli sayıda devlet memurların göndermek gerekiyordu (Abdrahmanov, 1991, s. 135, 143144, 148). Sovyet arşiv belgelerinden anlaşıldığına göre Basmacı Hareketini önlemek amaciyla Sovyet hükümeti bölgelere askerî önlemlerle beraber siyasî-ideolojik ve ekonomik tedbirler alarak bunları kısa süre içinde gerçekleştirmek zorunda kalmıştır (KC SB MDA, fon.10, liste.1, dosya. 204: 41-45; fon.10, liste.1, dosya. 253: 197-201).

1920'li yılların sonu-1930'lu yılların başında Basmacı Hareketi ile birlikte Kırgız ÖSSC'i terk hareketleri kaydedilmiştir. Genellikle sınır bölgelerde yaşayan ve Sovyet hükûmetinden memnun olmayan Kırgızlar, kendi istekleriyle Çin'e göç etmeye başlamışlardır. Varlıklı ailelerle birlikte onların akrabaları, orta halli hatta fakir yaşayanlar da Çin'e göç etmişlerdir. (KC SB MDA, fon. 10, liste. 1, dosya. 281:115; KC SB MDA, fon. 10, liste. 1, dosya. 361: 116). Çin'e giden ailelerin Kırgızistan'da kalan mülkleri, hayvanları, devlet tarafından hemen müsadere edilerek kolhozlara aktarılmıştır. Bu durumu önlemek

\footnotetext{
${ }_{16}$ Canıbek Kadı Sagımbay Uulu (Oğlu): 1869'da Oş vilayetine bağlı Özgön ilçesinin Köldük köyünde doğmuştur. O, Ekim İhtilali'ne kadar Rus Çarlığı hâkimiyeti döneminde Türkistan eyaletinin Fergana vilayeti Oş uezdine bağlı, Ak-Car volostunun yöneticisi idi; aynı zamanda kadılık görevini yürütüyordu. Canıbek Kadı'nın, başında bulunduğu silâhlı basmacı kolu, Kırgızistan'ın güneyinde faaliyet gösteren en büyük ve güçlü kollardan biriydi. Yaklaşık on yıl Sovyetlerle mücadele eden Canıbek Kadı en sonunda 1931 yılında Çin'e gitmek zorunda kalmıştır.

SEFAD, 2019; (42): 341-360
} 
için Sovyet hükümeti göç yaşanan bölgelerde sosyalizm yönünde siyasî propaganda faaliyetlerine öncelik verdiği bilinmektedir (OBDA, fon. 1, liste 1, dosya. 318:11).

Cusup Abdrahmanov, 28 Ocak 1931'de kaleme aldığı günlüğünde, Karakol ilçesinden bir köylü ile Isık-Göl ilçesi İcra Komitesi başkanının, Kırgızların aynı yılın bahar aylarında topluca Çin'e göç edeceği yönünde kendisine bilgi verdiklerini yazar. Cusup Abdrahmanov, kendisine ulaşan bilgiyi dönemin Tüm Birlik Komünist Partisi Kırgizistan Vilayet Komitesi birinci sekreteri Aleksandr Şahray'a aktardığını, fakat Aleksandr Şahray'ın konuya iyimser baktığını belirtir. Abdrahmanov günlüğünde, Sovyet yönetimi zamanında Kırgızların Çin'e kaçmalarını düşünmenin çok zor, ama mümkün olduğunu belirterek, dış ülkeye sığınma hareketinin temel sebebini tahıl üretip devlete teslim etme mecburiyetine bağlar ve bunu çok sert bir uygulama olarak görür (Abdrahmanov, 1991, s. 153). Çok geçmeden aynı sene 12 Şubat tarihinde göç ile ilgili aşağıdaki satırları bırakmıştır: "Birçok köylünün tohumlarına devlet tarafindan el konuldu. Birçok kişinin să̆dıkları son inekleri de ellerinden alındı. Baharın gelmesiyle birlikte Kırgızların Çin'e sığınması başlayacak gibi görünüyor, hatta şu anda 40 çiftlik Kırgızistan'ı terk etmeye yetişti. Ancak sorun, Kırgızların kaçacağı gerçeği değil, kendi meslektaşlarımı Çin'e kaçma ihtimalinin olduğunu ve onu önlemek için gerekli önlemleri alma konusunda ikna edemediğimdedir" (Abdrahmanov, 1991, s. 156).

1930'lu yılların başlarında kuraklıktan dolayı Sovyetler Birliği'nin pek çok bölgesinde sunî açlık ortaya çımıştır ve Kırgızistan'a komşu Kazakistan'ın tüm ilçelerinde şiddetli bir açlık baş göstermiştir. Tarımı kolhozlaştırma çerçevesinde Kazakları zorla yerleşik hayata geçirme, onların başlıca geçim kaynağı olan hayvan sürüleri ve başka özel mülklerinin ellerinden alınması, yiyecek ürünlerinin devlete teslim etme, varlıklı kesime fazla vergi uygulamaları Kazakistan'da korkunç boyutta açlı̆̆ı ortaya çıkarmıştır.

Kolhozlaştırmanın özellikle Kazakistan'da acımasız bir şekilde yürütülmesi, dönemin Kazakistan Komünist Partisi birinci sekreteri olan Filip Goloşçekin'in acımasız şahsından ve keyfî uygulamalarından da kaynaklanmıştır. Kazakistan'da 1925 yılında göreve başlayan Goloşçekin, Kazak köylerinde Sovyet yönetiminin bulunmadığını, zenginlerin yönetimi ve kabilelerin hâkimiyetinin olduğunu ileri sürerek bu ülkeye bir küçük Ekim Devriminin gerektiğini iddia etmiştir (Kurmangaliyeva Ercilasun, 2016, s. 15-16). Kazakistan ilçelerinden merkez şehir Almatı'ya açlık hakkında resmî bilgiler ulaştırılmasına rağmen ne pahasına olursa olsun tahıl, et ve diğer hayvancılık ürünlerini devlete zorunlu teslim planını yerine getirmeye çalışan bolşevik liderlerini Kazakistan halkının açlı̆̆a kapıldığı durum hiç ilgilendirmemiştir (Kindler, 2012, s. 173).

Bolşeviklerin icraata geçirdiği politikalar sonucunda yüzyıllar boyunca kalıplaşmış göçebe hayvancılığa dayalı geleneksel Kazak ekonomisi çökmüştür. Bu dönemde yaşanan açlık felaketinden büyük sayıda Kazak nüfusu azaldı, yüz binlerce insan da komşu Sovyet ülkelerine hatta SSCB dışına göç etmek zorunda kaldı. Birçok Kazak hayatını kurtarabilmek için Kırgızistan'a sığınmıştır. O dönemin seçkin Kazak devlet adamı Turar Rıskulov'un Moskova'ya, J.Stalin'e gönderdiği 9 Mart 1933 tarihli mektubunda verdiği bilgiye göre Kazakistan'ı terketmek zorunda kalan Kazaklardan Kırgızistan'da ${ }^{17} 100$ bin kişi bulunuyordu. Adı geçen mektupta Turar Rıskulov açlık ve salgın hastalıklar sebebiyle Kazakların, özellikle çocukların ölüm oranının ve Kazakistan'ın içindeki ilçelere aynı

${ }_{17}$ Kırgızistan Kazakistan'a komşu olduğundan Kazaklar buraya da göç etmişlerdir. Bu sebeple aynı mektubun kopyasını Turar Rıskulov Kırgızistan Vilayet Komitesine de yollamıştır. 
zamanda başka cumhuriyetlere göçün oldukça artmasından duyduğu endişesini bildirmiştir. T. Rıskulov Kazakların hayvan sayılarının azalması ve göç etmelerinin bir sebebi olarak hızlı bir şekilde kolektif çiftliklerin kurulması ve hayvanları devletleştirme oranının peşinde hareket eden yerli Sovyet makamlarının da suçlu olduğunu belirtmiştir. (KC SB MDA, fon. 10, liste. 1, dosya. 506: 27-29). C.Abdrahmanov'un başında bulunduğu Kırgızistan cumhuriyeti hükümeti Kazak göçmenlerine yapabileceği kadar yiyecek bakımından yardım etmeye çalışmış, darı ve mısır gibi ürünleri dağıtılmış, onlar için beslenme noktaları, çocuk evleri organize edilmiş, bazı Kazaklar kolhozlara kabul edilmişlerdir.

Cusup Abdrahmanov, 1930-1933 yıllarında Kazaklar arasında korkunç boyutta ortaya çıkan kıtlıktan dolayı endişe etmektedir. 25 Şubat 1932'de kaleme aldığı günlügü̈nde Frunze şehrinin çevresinde açlık ve fakirlikten dolayı Kırgızistan'a göç edip gelen Kazakların çadırlarından meydana gelen ikinci bir "şehrin" ortaya çıktığını belirtir. Bu Filip'inn's faaliyetinin sonucu olduğunu göstererek sadece O'nun suçu mu? diye soru sorar. Devaminda Kırgızistan'da devlete et teslimi amaciyla hayvan kesimine devam edilirse Kırgızların da Kazakların aynı durumuna düşeceğinin kaçınılmaz olduğunu yazmaktadır (Abdrahmanov, 1991, s. 184-185). Özellikle belirtilmesi gereken husus, Kirgızistan Özerk Sovyet Sosyalist Cumhuriyetinde Kazakistan gibi açlığın ortaya çıkmamasında Cusup Abdrahmanov'un katkısı büyüktür, bu konuda birçok araştırmacılar hemfikirdirler. Çünkü o dönemde tüm SSCB çapında halkın elindeki tüm tahıl ürünlerin ziraat fonlarına aktarılması uygulanıyordu. Kırgız ÖSSC ise devlete tahıl teslim etme planını yerine getirmemiş̧ir. Komparti direktiflerine rağmen Halk Komiserler Kurulu başkanı Cusup Abdrahmanov'un buyruğuyla tahıl ürünleri cumhuriyet halkına ve açlıktan dolayı Kırgızistan'a sı̆̆ınan Kazaklara dağıtılmıştır ve sonuçta binlerce kişinin hayatını kurtarmıştır. Fakat bu faaliyet Sovyet yönetimi tarafından olumsuz değerlendirilmiştir, 1933'te Cusup Abdrahmanov başta olmak üzere Kırgızistan'ın diğer yöneticilerine kınama cezaları verilerek görevlerinden alınmıştır (Abdrahmanov, 2001, s. 280).

Cusup Abdrahmanov sonradan Moskova'da bulunan parti içindeki disiplini incelemekle yükümlü Tüm Birlik Komünist Partisi Merkezî Teftiş Komisyonu başkan yardımcısı Antipov'a yazdığı açıklamada durumu böyle anlatmaktadır:

"1932 yılının bahar aylarında kütle halinde Kırgızistan'a göç eden Kazaklar arasında açlıktan dolayı insan kayıpları görülmeye başladı. Bu durum ben dâhil birçok Kırgıizistan yöneticilerini korkuttu. Biz Komünist Partinin Orta Asya Bürosu'nun Kırgızistan'dan talep ettiği tahıl hazırlama planının cumhuriyete aşırı yüklendiğini düşündük. Ve Kazak göçmenlerle bağlantılı olarak söz konusu planın gerçekçi olmadığına dair şüphelenmeye başladık. Böyle bir durumda Kırgızistan yöneticilerinden Aleksey Şahray, Bayalı İsakeev ile planı yerine getirmenin çok zor olduğunu konuştuk. Ben "Cumhuriyeti, Kazakistan'ın vaziyetine getirmektense, görevlerimizden alsınlar" diye öneride bulundum, ikisi de benim görüşümü desteklediler" (Abdrahmanov, 1991, s. 47-48). Cusup Abdrahmanov 1917 Ekim devriminden sonra kendini geliştirererek sosyalizme samimiyetle kendini adayan siyasetçi idi. Her zaman kendi vatanının ve Kırgızların çıkarlarını savunan devlet adamı olmasından dolayı meslektaşları tarafından katılaşmış milliyetçi olarak kabul edildiğini günlügünde yazmaktadır.

$\overline{18}$ Burada Filip İsayeviç Goloşçekin (1876-1941) kastedilmektedir. Filip İsayeviç Goloşçekin 1925-1933 yılları arasında Kazakistan Komünist Partisi 1. sekreteri görevinde bulundu. F.Goloşçekin'in başkanlığında yürütülen kolhozlaştırma uygulaması sonucu Kazakistan'da 1932-1933 yıllarında korkunç bir açlık ortaya çıkmıştır.

SEFAD, 2019; (42): 341-360 


\section{SONUÇ}

Kırgiz Sovyet devletinin kurucularından Cusup Abdrahmanov Kırgızistan'da Sovyet döneminin ilk yıllarındaki tanınmış liderlerdendir. Eserlerinin içinden gizli kaleme aldığı günlüğü Sovyet tarih biliminde sosyalist yapılanma meseleleri tek taraflı yansıtıldığından dolayı birçok önemli olaya ışık tutmaktadır. Yazar sosyalist kuruluşa geçiş süreci, ekonomide uygulanan sanayileşme, kolhozlaştırma, göçebe Kırgızların yerleşik hayat tarzına geçirilmesi, Kırgızistan'daki siyasi durum ve kültür siyaseti gibi birçok konuda ayrıntılı bilgiler paylaşmaktadır. Günlük, geçmişte çoğunluğu göçebe olan Kırgızların geleneksel hayatının Sovyet yönetimi tarafından kökten değiştirilmekte olduğunu ve Kırgız toplumunun yeni şartlara zorla adapte edilmeye çalışıldığını ortaya koymaktadır.

Cusup Abdrahmanov o dönemde yeni kurulan Sovyet yönetimine ve V. Lenin'in prensipleri ile fikirlerine kalpten inanarak sadık kalmıştır. Günlügünde Lenin vefat ettikten sonra Stalin'in zorlayıcı reformlarını sık sık eleştirmektedir. Lenin'in kolhozlaştırma sürecinde yavaş yürütülmesi ve baskı kullanılmaması gerektiğini savunduğu bilinmektedir. Fakat 1929'dan itibaren J.Stalin başında bulunduğu üst yönetim kolhozlaştırmayı gerçekleştirmede şiddet uygulamaya geçmiştir. Günlük sayfalarından anlaşıldığı üzere Cusup Abdrahmanov ilk başta sosyalist fikirleri desteklemesine rağmen, zamanla tereddüte düştüğü ortaya çıkmaktadır. Günlüğün her sayfası yazarın Kırgızistan'da da örneklerinin görüldüğü Sovyet rejiminin arasında memnuniyetsizliğe yol açan sosyoekonomik konularda zorlama politikaları hakkında sürekli endişelerine ve şüphelerine işaret etmektedir. Günlügünde Sovyet yönetiminin sınıf mücadelesini körüklemesini, köylüleri kolhozlara alınmasında çok ağır baskı yöntemlerinin kullanılmasını, sanayileşme, yerleşik hayata geçiş ve sosyalist kültürü toplumla benimsetme sürecindeki hataları tenkit etmektedir. Bazen toplantılar sırasında bu konularda yeri geldiği zaman kendi fikirlerini çekinmeden söylediğini kaydetmektedir. Böyle bir durumun halkın gözünde Sovyet yönetiminin itibarının sarsılacağına yol açabileceği ihtimalini belirtmektedir.

Günlügünü tahlil yoluyla C. Abdrahmanov'un yetenekli ve vatansever devlet adamı olduğu tespiti ortaya çıkmaktadır. O'nun her zaman Kırgızların menfaatini ön plana koyduğunu, cumhuriyetin sosyoekonomik ve kültürel alanlarda kalkınması ve sosyal hizmetlerin iyileştirilmesi konusunda çok çaba harcadığını görebiliriz. Ayrıca Sovyet döneminde ideoloji gereği kasıtlı araştırılmayan 1920'lerin sonu ve 1930'lu yılların başında meydana gelen Kırgızların Çin'e gönüllü göçü, Basmacı Hareketinin tekrar yayılması, açlıktan dolayı Kırgızistan'a göç eden Kazakların durumu vb. olaylar ve ortaya çıkış sebepleri hakkında çok ayrıntılı bilgileri sunmaktadır. Tarafımızdan yapılan analiz C. Abdrahmanov'un günlüğünde 1920-1930'lardaki Kırgızistan tarihi üzerine verdiği bilgiler ile bilimsel kaynaklardaki hatta Sovyet arşiv belgelerindeki malumatların birbiriyle örtüştüğünü göstermektedir. Günümüzde C. Abdrahmanov'un günlüğü 1920-1930'lu yıllardaki Kırgizistan'ın hatta Orta Asya'nın siyasî, sosyoekonomik ve kültür tarihinin araştırılmasında öncelikle başvurulması gereken değerli bir kaynaktır. Ayrıca yazarın bu dönemde Kırgızistan'daki Sovyet uygulamalarına devlet adamı olarak bizzat iştirak etmesi ve şahsî gözlemlerinin kaydedilmiş olması bu kaynağın önemini daha da arttırmaktadır. 


\section{SUMMARY}

The article deals with famous Kyrgyz statesman Jusup (or Yusup) Abdrakhmanov's life and activities, as well as evaluation of his diary as a historical source. Jusup Abdrakhmanov was born on 28 December 1901 in Chirkei village, Karakol region, nowadays Issyk-Kul district. As he was from a well-off family, he got an education in Russian schools. But due to explosion of 1916 Revolt he and his family had to take refuge in China. J. Abdrakhmanov lost all his family besides of younger brother during 1916 Revolt. Later he came back to Kyrgyzstan and served in the Red Army.

During 1920-1927 years, he worked in several high-level positions in Soviet Central Asia. In 1927 he was appointed as the president of the Council of People's Commissariat of the Kyrgyz Autonomous Soviet Socialist Republic. In 1933 he was removed from office, between 1933-1937 years he lived and worked in Russia. Unfortunately, he was arrested and died in the time of 1937-1938 Repression. He was accused as nationalist, panturkist, member of Alash-Orda organization and Social-Turan party. In 1958 he was rehabilitated. After independency one of big streets of Bishkek was named after J. Abdrakhmanov and many of his monuments had been built in the republic.

J. Abdrakhmanov contributed a lot to political, social-economic and cultural development of Soviet Kyrgyzstan. J. Abdrakhmanov also known as founder of Kyrgyz statehood during the Soviet period. Owing to his steady efforts in 1924, Kara Kyrghyz Autonomous Region was established. In 1926 the official name of the region changed to the Kyrgyz Autonomous Soviet Socialist Republic (Kyrgyz ASSR). In 1936, Kyrgyz ASSR achieved the status of a full republic of the Soviet Union.

Besides being a statesman, J. Abdrakhmanov is known for his several historical works devoted to 1916 Revolt, 1917 the February and October Revolutions, Soviet period Kyrgyzstan history. At the same time, he brought us his diary which was written in Russian language secretly. J.Abdrakhmanov's daughter, Lenina Abdrakhmanova (1936-2017), had kept this diary for many years. In post-Soviet years J.Abdrakhmanov's diary had been published as a book in Russian as well as Kyrgyz languages. J.Abdrakhmanov's diary contains records written between 1928 and 1931. The author recorded his personal opinions in the diary. The diary included very detailed and interesting materials. We can read the author's thoughts, feelings and concerns about the future of his homeland Kyrgyzstan and its people. In his diary, he wrote that he could not be whole bolshevik and although he had many friends, he generally felt himself lonely.

The author of the diary shares detailed information on the transition process to socialist organization such as industrialization in economics, collectivization of agriculture, sedentarization of nomadic Kyrgyz people, political situation of that time and Soviet cultural politics in the region. J. Abdrakhmanov, due to his realistic approach to the socio-economic issues planned by the Soviet regime, was able to see the shortcomings of the activities of government such as industrialization, collectivization, sedentarization and disseminating socialist culture in the late 1920s and 1930s. Therefore, in his diary, the author generally evaluated the Soviet government policies negatively.

J.Abdrakhmanov did not support rapid industrialization at the expense of the peasants, as the Soviet government planned to sell the wheat produced in agriculture to foreign states to obtain the money needed to develop the industry. In his diary, he was 
concerned about the failures and extremes of the Soviet government during the industrialization process. In 1927-1933s when he worked as president of the Council of People's Commissariat of the Kyrgyz Autonomous Soviet Socialist Republic, owing to his initiatives, many industrial factories and railways had been built. As his diary evidence, J.Abdrakhmanov tried to solve the economic and social problems of the regions through the newly established industrial factories there.

According to J. Abdrakhmanov the collectivization should be carried out gradually. Thus, in his diary he objected and often criticized the use of very heavy oppression methods to peasants in the process of collectivization. According to the Soviet government plan, the sedentarization of nomads would guarantee the collectivization. Therefore, the nomadic people were forced to settle and to enter the collective farms. J.Abdrakhmanov criticized the acceleration of the sedentarization in his diary.

The diary of J.Abdrakhmanov allows us to know events that were unknown in Soviet historiography such us the voluntary migration of the Kyrgyz to China, strengthening of the Basmachi Movement. These events took place in the late 1920s and early 1930s. Author analyzed reasons of these events in diary. In his point of view, main reasons were excessive political and social-economic policy conducted by the Soviet regime. In addition J. Abdrakhmanov's diary points out at the situation of Kazakh people who had migrated to Kyrgyzstan due to the terrible famine in Kazakhstan between 1930 and 1933. Diary pages show that J. Abdrakhmanov was worried and saddened by the Kazakh famine of 1930-1933.

J. Abdrakhmanov's diary also presents data about Soviet applications in cultural sphere. In the context of the establishment of socialist culture, expanding literacy, development in science, literature and art were aimed. In this period Arabic alphabet changed to Latin in Kyrgyzstan. As evidenced by his diary he argued that the official correspondence language of the republic should be in Kyrgyz.

His diary sheds light on many important unknown events in 1920-1930s, especially on the issues of socialist reorganizations in Soviet Kyrgyzstan. The Soviet official historiography deliberately kept silent or interpreted these problems within the framework of the Communist ideology. Also, comparison of the J. Abdrakhmanov's diary materials with other scientific sources and the Soviet top-secret archive documents show that they coincide with each other. Moreover, the fact that the author himself participated directly and witnessed in the Soviet socialist reorganizations increases the importance of the diary as a historical source. Consequently, we can state that J. Abdrakhmanov's diary is the most valuable source on Soviet period Kyrgyzstan's political, socio-economic and cultural history in 1920s and 1930s as well as all Central Asian history. 


\section{KAYNAKÇA}

\section{Arşiv Kaynakları}

KC SB MDA, fon.10, liste.1, 201, 203, 204, 281,253, 229, 361, 363, 506 numaralı dosyalar.

KC SB MDA, fon.6, liste.1, dosya. 30.

Kırgızistan Cumhuriyeti Siyasî Belgeler Merkez Devlet Arşivi, (KC SB MDA), fon.10, liste.15, dosya.22. C. Abdrahmanov'un şahsî dosyası.

OBDA, fon.1, liste 1, 298 ve 318 numaralı dosyalar.

Oş Bölgesel Devlet Arşivi (OBDA) fon. 79, liste.1, dosya.14.

\section{Diğer Kaynaklar}

Abdırakman Uulu, C. (2018). Kırgızstan. A. Kubatova (Ed.), Bişkek: Gülçınar.

Abdrahmanov, Y. (1991). 1916. Dnevniki. Pisma k Stalinu. C. Cunuşaliyev ve İ.Semenov (Giriş yazarları). Frunze: Kirgizstan.

Abdrahmanov, Y. (2001). İzbrannıye Trudı. C. Cunuşaliyev, İ.Semenov ve C. Kanimetov (Ed.), Bişkek: Şam.

Abducaparov, H. ve Bekboyev, A. (2002, Aralık). Vklad Yu.Abdrahmanova v Stanovlenii Kırgizskoy Gosudarstevennosti. Körünüktü̈̈ Mamlekettik cana Koomduk İşmer Yusup Abdrahmanovdun 100 Cildıgına Arnalgan "El Dep Sokkon Jürok" attuu Respublikalık İlimiyPraktikalık Konferentsiyanın Materialdarı içinde (s.23-28). Bişkek: Biyiktik.

Baktıgulov, C. (1971). İ İstorii Perehoda Kirgizskogo Krestyanstva k Osedlosti i Sotsiyalistiçeskim Sposobam Hozyastvovaniya. Frunze: Kirgızstan.

Baktıgulov, C. (1990). Kollektivizatsiya Kirgizskogo Aila: Noviy Vzglyad. Kommunist Kirgizstana, (3), 83-89.

Cumanaliyev, A. (2005). Politiçeskaya İstoriya Kırgızstana. Bişkek:Tarih Enstitüsü.

Cunuşaliyev, C. (2002, Aralık). Uluu İnsan, Körünüktüü Mamlekettik cana Koomduk İşmer Yusup Abdrahmanovdun 100 Cildıgına Arnalgan "El Dep Sokkon Jürok" attuu Respublıkalık İlimiy-Praktikalık Konferentsiyanın Materialdarı içinde (s. 5-10). Bişkek: Biyiktik.

Cunuşaliyev, C. (2003). Vremya Sozidaniya i Tragediy 20-30-e Godı XX veka. Bişkek: İlim.

Fitzpatrick, Sh. (2005). Tear Off The Masks!: Identity and Imposture in Twentieth Century Russia. Princeton: Princeton University.

Kindler, R. (2012, May-June). Vıjivaniye Kak Sotsiyalnıy Konflikt-Naseleniya Kazahstana vo Vremya Goloda 1932-1933 gg. B. Ayagan (Ed.). Great Famine in Kazakhstan: Tragedy of the Nation and the Lessons of History", International Scientific Conference, Collection of Materials içinde (s.173-180). Astana: The Institute of State History.

Kurmangaliyeva Ercilasun, G. (2016). Kazakistan ve Kirgizistan'da Kolektifleştirme: Sözlü Tarih Çerçevesinden Bir Bakiş. Gazi Türkiyat, (19), 11-22.

Tursunov, E. (2001). Cusup Abdrakmanov cana Anın Talamdaştarı. Bişkek: Bişkek Gumanitardık Universiteti.

Viola, L. (2007). Unknown Gulag. New York: Oxford University.

Asanbayev, U. (1968). Sovetı Kirgizii v Borbe Za Stroitelstve Sotsiyalizma (1929-1932 gg.). Frunze: Kurgizstan.

SEFAD, 2019; (42): 341-360 


\section{EKLER:}

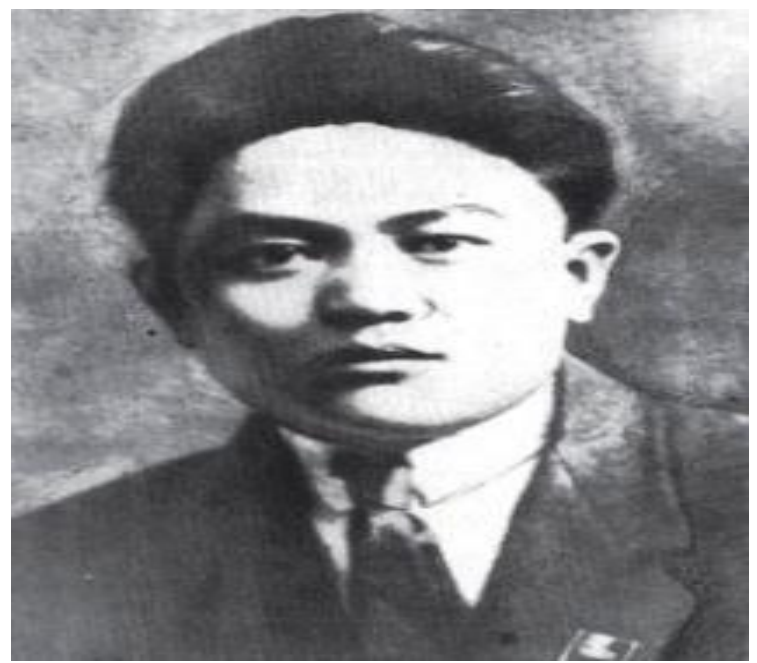

Resim 1. Cusup Abdrahmanov (1901-1938)

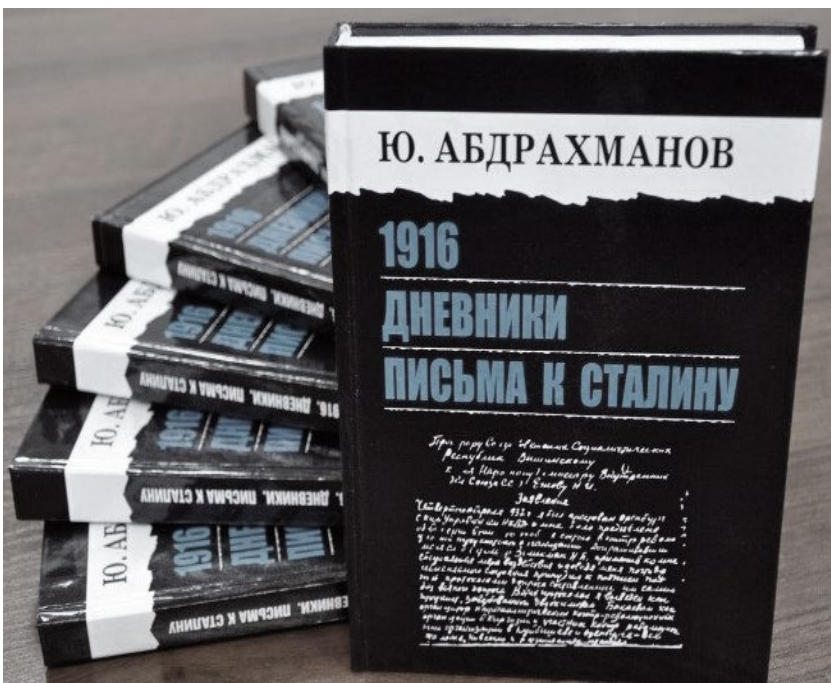

Resim 2. C.Abdrahmanov'un günlüğünün 2013 'te Rusça yayınlandığı kitap hali

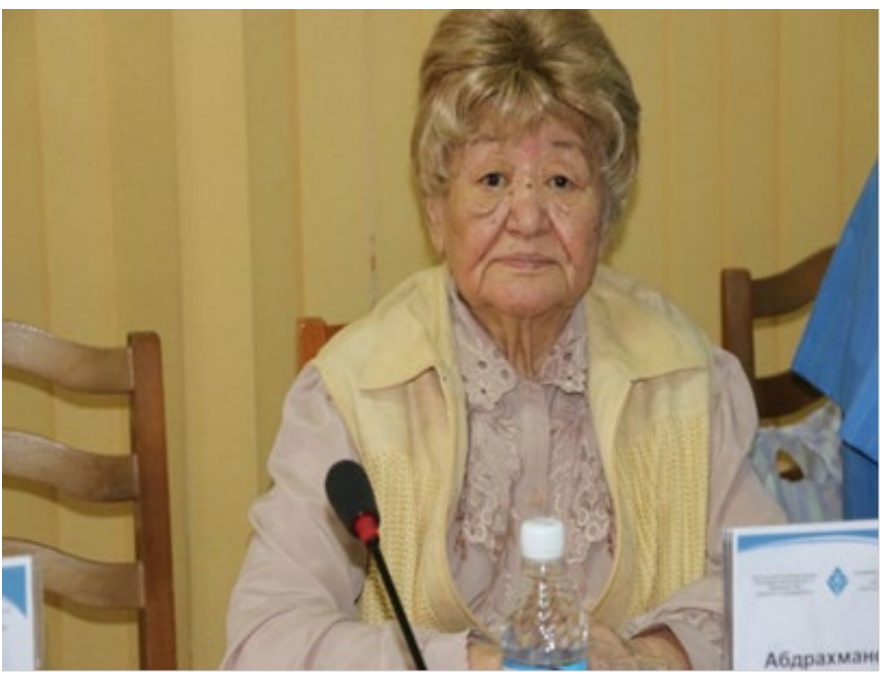

Resim 3. C.Abdrahmanov'un kızı Lenina Abdrahmanova 